\author{
Микуланинець Леся Михайлівна \\ кандидат мистецтвознавства, доцент, \\ старший викладач кафедри співу, \\ диригування і музично-теоретичних дисциплін \\ Мукачівського державного університету \\ ORCID 0000-0002-6346-6532 \\ I.mikulaninets@gmail.com
}

\title{
МІФОТВОРЧІСТЬ ЯК СКЛАДОВА ЖИТТЄПИСУ МИТЦЯ
}

\begin{abstract}
Мета роботи - на основі аналізу та узагальнення праць у галузі фрілософії, соціології, мистецтвознавства та культурології уточнити сутність поняття “міфотворчість", висвітлити специфіку біографічного міфу, виявити зміст міфотворчості у вимірі життєпису митця. Методологія дослідження полягає у застосуванні аналітичного, культурно-контекстуального, компаративного, системно-структурного, історичного, аксіологічного методів для розкриття міфотворчості як структурного компоненту літопису особистості. Наукова новизна. У статті конкретизовано сенс міфотворчості з позиції біографічного підходу, аргументовано думку, що вищезазначений феномен $\epsilon$ складовою хронік креативної персони. Висновки. Міф у різні історичні періоди поставав ірраціональним виразником найстійкіших ідей, які людство транслювало у вигляді поступу в матеріальній і духовній сферах. 3 XX століття означене явище раціоналізується, завдяки чому стає засобом не тільки інтуїтивного осягнення, але і логічного осмислення цивілізаційних процесів. Однією з форм побутування та поширення міфу є міфотворчість. Для неї характерно, основуючись на стабільних психологічних, ідеологічних та культурних домінантах певного часу, будувати модель як цілого суспільства, так й індивіда, що функціонує у ньому. Починаючи з епохи романтизму, вона активно інтегрується у літопис креативної персони, стає ії структурним компонентом. Біографічний міф - комплексне відтворення життєвого шляху майстра з позиції суб'єктивного та громадського художнього виміру, виявлення значення його постаті в існуванні історичних і соціальних явищ країни, висвітлення у діяльності зв'язку свідомих й підсвідомих кодів цивілізації. Міфотворчість як складова хронік митця є фрілософсько-поетичним розумінням його буття крізь призму світоглядних орієнтирів конкретної доби, політичної та культурної ситуації, провідних ідеалів й утопій. Вона ґрунтується на реальних епізодах життя, які отримали багаторазову експлікацію, наукове осмислення біографрами та шанувальниками послідуючих епох.
\end{abstract}

Ключові слова: міф, міфотворчість, біографічний міф, життєпис, митець.

Микуланинец Леся Михайловна, кандидат искусствоведения, доцент, старший преподаватель кафредры пения, дирижирования и музыкально-теоретических дисциплин Мукачевского государственного университета

\section{Мифотворчество как составляющая жизнеописания художника}

Цель работы - на основе анализа и обобщения работ в области фрилософии, социологии, искусствоведения и культурологии уточнить сущность понятия "мифотворчество”, показать специфику биографического мифа, выявить содержание мифотворчества в измерении жизнеописания художника. Методология исследования заключается в применении аналитического, культурно-контекстуального, сравнительного, системно-структурного, исторического, аксиологического методов для раскрытия мифотворчества как структурного компонента летописи личности. Научная новизна. В статье конкретизирован смысл мифотворчества с позиции биографического подхода, аргументировано мнение, что вышеупомянутый феномен является составной хроник креативной персоны. Выводы. Миф в разные исторические периоды был иррациональным выразителем самых стойких идей, которые человечество транслировало в виде развития материальной и духовной сфер. C XX века обозначенное явление рационализируется, благодаря чему становится средством не только интуитивного постижения, но и логического осмысления цивилизационных процессов. Одной из форм бытования и распространения мифа является мифотворчество. Для него характерно, основываясь на стабильных психологических, идеологических и культурных доминантах определенного времени, строить модель как всего общества, так и индивида, который функционирует в нем. Начиная с эпохи романтизма, оно активно интегрируется в летопись креативной персоны, становится ее структурным компонентом. Биографический миф - комплексное воспроизведение жизненного пути мастера с позиции субъективного и общественного художественного измерения, выявление значения его фигуры в существовании исторических и социальных явлений страны, раскрытие в деятельности связи сознательных и подсознательных кодов цивилизации. Мифотворчество как составляющая хроник художника является философскопоэтическим пониманием его бытия сквозь призму мировоззренческих ориентиров конкретной эпохи, политической и культурной ситуации, ведущих идеалов и утопий. Оно основывается на реальных эпизодах жизни, получивших многоразовую экспликацию, научное осмысление биографами и поклонниками в последующие эпохи.

Ключевые слова: миф, мифотворчество, биографический миф, жизнеописание, художник.

Mykulanynets Lesya, Senior Lecturer in department of singing, conducting and music-theoretical disciplines of Mukachevo State Universitry, candidate of Arts, Associate Professor

Myth-creation as a composition of the artist's biography

The purpose of the article. On the basis of analysis and generalization of works in the field of philosophy, sociology, art and cultural studies to clarify the essence of the concept of "myth-creation", to highlight the specifics of the biographical myth, to reveal the content of myth-creation in the measurement of the artist's biography. The methodology of the research is to apply analytical, cultural-contextual, comparative, system-structural, historical, axiological methods for revealing myth-creation as a structural component of the person's chronicle. Scientific novelty. The article

() Микуланинець Л. М., 2019 
specifies the meaning of myth-creativity from the standpoint of a biographical approach, arguing that the phenomenon mentioned above is part of the chronicle of a creative person. Conclusions. The myth in various historical periods appeared to be an irrational expressing of the most persistent ideas in which humanity was transmitted in the form of advancement in the material and spiritual spheres. Since the twentieth century, this phenomenon was rationalized, thereby becoming a means of not only intuitive comprehension but also a logical understanding of civilization processes. One of the forms of existence and distribution of myth is myth-creation. Basing on the resistant psychological, ideological and cultural dominance of a certain time, for it is typically to build a model for both the whole society and the individual which functionating in it. Since the epoch of romanticism, it actively integrates into the chronicle of a creative person and becoming its structural component. Biographical myth is a complex of reproduction of the way of master's life from the position of subjective and social artistic being, revealing the significance of his figure in the existence of historical and social phenomena of the country, coverage in his activities the communication of conscious and subconscious codes of civilization. The myth-creating as a part of the chronicle of the artist is a philosophical and poetic understanding of his being through the prism of ideological orientations of a particular age, political and cultural situation, leading ideals and utopias. It is based on real episodes of life that have received multiple explications, scientifically reflected by biographers and admirers of subsequent epochs.

Key words: myth, myth-creating, biographical myth, biography, artist.

Актуальність теми дослідження. Формування постіндустріального суспільства значно впливає на трансформацію культурної ситуації. Провідну роль у трансляції загальної свідомості сьогодення отримує міфотворчість, яка є проявом протиріч між тенденціями соціальної еволюції і адаптивним потенціалом окремої персони. Масштабне її поширення пов'язане з потребою співвіднести сучасний досвід з духовною парадигмою попередніх епох, а також необхідністю усвідомити потенціал міфу у процесі моделювання нової системи цінностей. Вищезазначене явище одночасно $є$ самовираженням homo sapiens на певному історичному проміжку його розвитку загалом, і конкретної особистості зокремa.

Цілком закономірно, що цивілізаційний поступ здійснюється завдяки діяльності митців. Тому осмислення і відтворення специфіки міфотворчості мусить відбуватися через осягнення біографії креативної персони.

У західноєвропейській науковій думці вже накопичена значна теоретична база, що може слугувати основою для новітнього розуміння означеного феномену у культурологічному та мистецтвознавчому вимірах. Серед фундаментальних слід назвати роботи, у яких міфотворчість розглядається як: етап розвитку матеріальної і духовної сфери (І. Гердер, Ф. Крейцер, Ф. Шлегел та ін.), суспільний факт (Р. Барт, С. Московічі, Г. Осипов, Е. Тофлер та ін.), складова психології (Т. Адорно, М. Веберн, Х. Ортега-і-Гассет, П. Штомпкі та ін.), структурний компонент медіакультури (А. Гідденс, Г. Кнабе, Е. Орлова, А. Фліер, Г. Шіллер та ін.) тощо. Окремі аспекти вивчення проблеми міфу в національній гуманітаристиці представлені дослідженнями І. Бичко, С. Кримського, В. Шинкарука, М. Поповича, Ю. Сєрова та ін. Однак, з огляду на цивілізаційні зміни у XXI столітті, вимагає подальшого аналізу як зміст питання міфотворчості, так і опанування її смислу з позиції життєпису творчої особистості.

Мета дослідження - на основі аналізу та узагальнення праць у галузі філософії, соціології, мистецтвознавства та культурології уточнити сутність поняття “міфотворчість”, висвітлити специфіку біографрічного міфу, виявити зміст міфотворчості у вимірі життєпису митця.

Виклад основного матеріалу. Загальновідомим є той фракт, що міфологія - світогляд, який характеризується ірраціональністю, оперуванням символами, намаганням встановити гармонію між суб'єктом і природою, суспільством й індивідом, бажанням через чуттєвий досвід усвідомити особливості влаштування космосу. Дві фундаментальні науки, ціллю яких є аналіз взаємовідношення середовища й людини, ролі персони в історії й сенсу їі буття - фрілософрія й теологія, беруть початок з міфології. Хоча домінувала вона в архаїчні часи, все ж таки трансформовані її прояви ми спостерігаємо у послідуючі епохи.

На початку XX століття зазначена проблема знову стає актуальною. Причиною стала тотальна структуризація життєустрою, намагання підпорядкувати його строгим логічним законам. 3'єднання ірраціонального початку міфу й раціональності ідеології індивіда Нового часу видозмінили смисл даного феномену. У роботах К. Юнга, Е. Фромма, Е. Ноймана він тлумачиться як глибинна ментальна побудова, що пов'язана з колективним безсвідомим. К. Леві-Стросс вперше визначив здатність міфу до класифікації та узагальнення цивілізаційного знання.

У подальшому це явище інтерпретується у різних вимірах: унікальний інтелектуальний метод вивчення світу (Б. Губман, К. Хюбнер); спосіб надання особистісного змісту хаосу (В. Піфоєв); засіб передачі культурної практики (Л. Леві-Брюль, Б. Малиновський) тощо. Тобто, можемо констатувати, що у XX столітті остаточно подолано судження про міф як виключно інтуїтивний, наївний погляд на космос. Його експлікація розширюється розумністю, закономірністю та організованістю, що сприяють досягненню певної стабільності соціального укладу.

Постмодернізм продовжує виробляти міфи. Для широких мас він виконує функцію розваги, психологічної розрядки. Однак, правляча політична верхівка, використовуючи його, формує думки і поведінку широкого загалу людей. На нинішньому етапі він інтегрується майже у всі сфери життєдіяльності - мистецтво, науку, філософію, причому зазвичай існує у синтезі з ними. 
Міф виникає у результаті міфотворчості, $€$ наслідком конструювання численних образних форм, що ілюструють ідеальну культурну модель. Сучасні науковці намагаються осягнути даний феномен через інтерпретацію його сутності.

Дослідниця А. Рамазанова трактує міфотворчість наступним чином: “ як об’єктивне явище соціальної реальності має позачасовий характер, і продукується свідомістю суспільства протягом всього історичного розвитку" (тут і далі переклад з російської наш - Л.М.) [5, 28]. Вчена концентрує увагу на надособистісному (громадському) змісті поняття. Виводячи його з конкретно визначеного епохального виміру, вона вказує на так званий “колективний розум”, який в конкретний проміжок цивілізаційної еволюції стає виразником її провідних ідей та прагнень. Цей підхід до міфотворчості характерний, в основному, для соціології.

В культурологічному аспекті міфотворчість розуміє Н. Сіняєва: “інструмент художньої організації матеріалу та засіб вираження певних “вічних" вихідних, стійких, національно-культурних моделей буття" [6, 91]. У даному контексті представлений феномен постає прийомом структуризації різноманітних термінів, ідей, символів, які побутують у стійких групах індивідів, виражають світоглядні модуси, і тим самим зводить їх фрілософрію у позачасове існування. Акцент на духовних і матеріальних надбаннях опосередковано відносить нас і до питання творчої особистості, яка власне будує мистецтво у всій його багатогранності.

Л. Воєводіна визначає міфотворчість в антропологічному ключі: “іманентна функція людської свідомості і спосіб відтворення культури в суспільстві, а також засіб соціального конструювання реальності" [1, 21]. Науковиця тлумачить термін в його двоїстості: з одного боку - якість, яка закладена в персоні від природи, що допомагає їй адаптуватися до оточуючих умов, з іншого - інструмент формування власного середовища, суб'єктивного макрокосмосу. Представлене поняття можна інтерпретувати як трансляцію «Я» концепції в цивілізаційному просторі. Таке бачення відкриває перспективи до осмислення міфотворчості як механізму, що будує історію персони, і чим значуща вона, тим багатший ïi мiфp.

Починаючи з XX століття міфотворчість стає складовою життєпису митця. Це засвідчує розвиток жанру біографії, для якого характерним є поєднання знань про історичні закономірності поступу певної країни (виражені в унікальній формі літератури) і буття конкретного митця. Метою є реконструкції образу епохи, фрілософії індивідуума, інтегрованого в неї. Одночасно, літопис розуміється як мистецько-комунікативна та науково-інтелектуальна частина культури.

Проникнення міфотворчості у хроніки майстра сягають своїм корінням доби романтизму, де проблема автора художнього зразку була ключовою. 3 цього часу доля креативної персони для широкого загалу іноді стає цікавішою, ніж її шедеври. Звичайно, найбільш яскраві приклади міфотворчості ми спостерігаємо у вербальних жанрах, оскільки часто їх герої ототожнюються із літератором. Однак, якщо митець не апелює до слова, тематика його опусів, образний зміст можуть інтерпретуватися дослідниками сублімацією життєвих подій. Це дає ще більший ґрунт для появи певних здогадок, переказів, які нібито пояснюють сенс їх діяльності. Міфотворчість як складова літопису особистості ґрунтується на так званому біографічному міфрі, що $є$ виразником типових ознак не тільки фрілософії окремої персони, але і тієї соціоісторичної ситуації, у якій вона здійснює своє існування.

На думку Т . Шеметової: “Біографрічний міфр - це міф Нового часу, він не може існувати без свого суб'єкта - автора, який усвідомлює первинну версію власної долі, що потім багаторазово переосмислюється як масовою свідомістю, так і художниками, дослідниками. На відміну від традиційних міфів, він не $є$ породженням колективного несвідомого, навпаки, саме колективна свідомість в різних формах знову і знову відтворює автобіографічний міфр" [7, 2 - 3.]. На нашу думку, у центрі даної експлікації є креативна персона - основоположник і популяризатор міфів про своє життя. Шляхом множинності інтерпретацій вони набувають загального поширення, укорінюються у пам'яті певної громади і через конкретний часовий проміжок дають наступним поколінням трансформований образ homo sapiens.

Розширює семантичне поле розуміння проблеми міфотворчості О. Нікітіна, яка визначає її у біографічному ключі: “міфр нової фрормації, тобто він є виразом колективної, а не авторської творчості, що втілює найбільш фундаментальні, стереотипні уявлення масової аудиторії про митця, як про героя певної культурної епохи. Джерелом цього міфу є безпосередньо творчість, творча поведінка і репутація митця або сформований ним самим автобіографрічний міф, але сфрерою його побутування завжди буде масова свідомість" [3, 218]. Можемо стверджувати, що представлена дефініція домінуючою вбачає креативну особистість, яка аналізується соціумом крізь призму її надбань у художній сфері. Дослідниця усвідомлює майстра активним суб'єктом цивілізаційного процесу, що через свою діяльність реалізовує провідні ментальні ознаки громадянського суспільства. У цьому вимірі суб'єкт як реально існуюча постать не функціонує, а живе у колективній пам'яті у фрормі міфу. Його хроніки стають відображенням і одночасно складовою міфотворчості.

І. Пюра досліджуваний нами френомен окремої постаті виводить на рівень літопису епохи і визначає її наступним чином: “комплекс ідей, що функціонують у суспільній свідомості, формують уявлення про видатну особистість і стають алгоритмом життя непересічних індивідів у певний історикокультурний період" [4, 2]. Такий погляд вибудовує модель побутування людства, у якій вихідною точ- 
кою буде життєпис митця, що постає транслятором парадигми певного часу. Міфотворчість експлікується не лише у вимірі відображення індивідуальних хронік майстра, але і цивілізаційного поступу.

Узагальнивши вищезазначене, констатуємо, що біографрічний міф - це певний образ митця, який вироблений уявою сучасників та послідуючих поколінь науковців, на основі його творчого портрету. Він багаторазово видозмінюється, ретранслюється через усталені ідеали, вірування, фрілософрію епохи, в яку декодовується його життєвий шлях.

Зміст понять "міфр", “біографрічний міфр" та "міфотворчість" підводить нас до розуміння останньої як частини літопису креативної персони. Основуючись на біографічному підході (сутністю якого є аналіз зв'язків між життєписом майстра і його здобутками, дослідження людського змісту історії), ми можемо прийти до умовиводу, що експлікація художніх досягнень відбувається у контексті тих міфів, які побутують у конкретній епосі. Їх фрундатором та транслятором є: автор (свідомо - поширюючи певні легенди про себе, чи несвідомо - через образні, поетичні, вербальні, звукові семантичні символи власних шедеврів), соціум, у якому він живе, дослідники та “споживачі" його діяльності в послідуючі періоди.

Висновки. Отже, аналіз праць, присвячених міфотворчості дозволив нам стверджувати, що міф у різні історичні періоди поставав ірраціональним виразником найстійкіших ідей, які людство транслювало у вигляді поступу в матеріальній і духовній сфрерах. 3 XX століття означене явище раціоналізується, завдяки чому стає засобом не тільки інтуїтивного осягнення, але і логічного осмислення цивілізаційних процесів.

Однією з форм побутування та поширення міфу є міфотворчість. Для неї характерно, основуючись на стабільних психологічних, ідеологічних та культурних домінантах певного часу, будувати модель як цілого суспільства, так й індивіда, що функціонує у ньому. Починаючи з епохи романтизму, вона активно інтегрується у літопис креативної персони, стає ії структурним компонентом.

Біографрічний міф - комплексне відтворення життєвого шляху майстра з позиції суб'єктивного та громадського художнього виміру, виявлення значення його постаті в існуванні історичних і соціальних явищ країни, висвітлення у діяльності зв'язку свідомих й підсвідомих кодів цивілізації.

Міфотворчість як складова хронік митця $€$ фрілософрсько-поетичним розумінням його буття крізь призму світоглядних орієнтирів конкретної доби, політичної та культурної ситуації, провідних ідеалів й утопій. Вона ґрунтується на реальних епізодах життя, які отримали багаторазову експлікацію, наукове осмисленнях біографрами та шанувальниками послідуючих епох.

Представлена стаття не вичерпує всі аспекти заявленої проблематики. Перспективними нам вважаються дослідження міфотворчості у соціально-політичному та культурологічному контекстах, у аспекті онтологічного осмислення мистецтва тощо.

\section{Лimepamyра}

1. Воеводина Л. Н. Мифотворчество как феномен современной культуры: автореф. дис. ... доктора философр. наук. : 24.00.01. Москва, 2002. 48 с.

2. Галанина Е. В. Миф как феномен современной культуры. Вестник Томского государственного университета. 2007. №305. С. $50-52$. 2011. $350 \mathrm{c}$

3. Никитина О. Э. Биографические мифы о русских рок-поэтах. Сан-Петербург: Гуманитарная академия,

4. Пюра І. В. Біографрічний міф митця початку XX століття в романі “Доктор Фаустус" Т. Манна: авторефр. дис. ... канд. мистецтвознавства: 17.00.01. Київ, 2003. 14 с.

5. Рамазанова А. Х. Особенности современного мифотворчества и мифосознания. Алматы: Вестник КазНу, 2011. 117 с.

6. Синяева Н. В. Мифотворчество русской художественной интеллигенции 1900-1930-х гг. Москва: Экон-Информ, 2010. 199 с.

7. Шеметова Т. Б. Биографический миф о Пушкине в русской литературе советского и постсоветского периодов : автореф. дис. ... доктора филол. наук: 10.01.01. Москва, 2011. 50 с.

\section{References}

Russian].

1. Voevodina, L. N. (2002). Myth-creation as a phenomenon of modern culture. Doctor's thesis. Moscow. [in

2. Galinina, E. V. (2007). Myth as a phenomenon of modern culture. Vestnik Tomskogo gosudarstvennogo universiteta, 305, pp. 50 - 52. [in Russian].

ja. [in Russian].

3. Nikitina, O. E. (2011). Biographical myths about Russian rock poets. St.-Peterburg: Gumanitarnaja akademi-

4. Pjura, I. V. (2003). Biographical myth of artist in the beginning of the twentieth century in the novel "Doctor Faustus" by T. Mann. Extended abstracts of candidate's thesis. Kyiv. [in Ukrainian]. Russian].

5. Ramazanova A. Kh. (2011). Features of modern myth-creation and myth consciousness. Vestnik KazNu. [in

6. Sinyaeva N. V. (2010). The myth-creation of the Russian artistic intelligentsia of the 1900s and 1930s. Moscow: Econ-Inform. [in Russian].

7. Shemetova T. B. (2011). Biographical myth about Pushkin in the Russian literature of the Soviet and postSoviet periods. Extended abstracts of doctor's thesis. Moscow. [in Russian].

10.06. 2019 рСтаття надійшла до редакції 29.04.2019 p. 